\title{
Quantification of phenolic and flavonoid contents and some biological activities of Ornithogalum sigmoideum Freyn \& Sint
}

\author{
Can Özgür YALÇIN 1,2 (D), Sezen YILMAZ SARIALTIN ${ }^{*}{ }^{*}$, , Derya ÇIÇEK POLAT ${ }^{4}$ (iD \\ 1 Department of Pharmaceutical Toxicology, Faculty of Pharmacy, Karadeniz Technical University, Trabzon, Turkey. \\ 2 Drug and Pharmaceutical Technology Application and Research Center, Karadeniz Technical University, Trabzon, \\ Turkey. \\ 3 Department of Pharmaceutical Toxicology, Faculty of Pharmacy, Ankara University, Ankara, Turkey. \\ 4 Department of Pharmaceutical Botany, Faculty of Pharmacy, Ankara University, Ankara, Turkey. \\ * Corresponding Author. E-mail: sezen.yilmaz@ankara.edu.tr (S.Y.S.).
}

Received: 11 April 2020 / Revised: 17 June 2020/ Accepted: 24 June 2020

\begin{abstract}
Ornithogalum L. is a genus containing approximately 200 species that grow in warm areas of Europe, Asia and Africa. 54 of these species grow naturally in Turkey. They have been used for various medicinal purposes such as emetic and against abscess since ancient times and today consumed as food especially in the eastern region of the Black Sea. Ornithogalum species were found to be rich in cholestane glycosides, cholestane bidesmosides, cardenolide glycosides, flavonoid glycosides and saponins. According to the health-promoting effects of these compounds; we aimed to study, antioxidant, anti-inflammatory and cytotoxic effects of aerial parts and bulbs of Ornithogalum sigmoideum as well as bioactive compounds. The antioxidant activity was determined using 2,2'-azino-bis (3ethylbenzothiazoline-6-sulphonic acid) (ABTS) and 2,2-diphenyl-1-picrylhydrazyl (DPPH) free radical scavenging assay. Anti-inflammatory activity of extracts was evaluated by the human red blood cell membrane stabilization method. Total phenolic and flavonoid contents were evaluated by Folin-Ciocalteu and aluminum chloride methods, respectively. The cytotoxic effects were evaluated on lung (A549), colorectal (HCT-116) and prostate (PC3) cancer cells using 3-(4,5-dimethylthiazol-2-yl)-2,5-diphenyltetrazolium bromide (MTT) assay. Methanolic extract of aerial part of $O$. sigmoideum exhibited the greatest anti-inflammatory and antioxidant activity in all methods determined. Supporting these results, the highest amounts of total phenolic and flavonoid were obtained from this extract. MTT cell viability results showed that aerial part extract of $O$. sigmoideum was induced cell death more than the bulb extract in every-three cell line and the PC3 cells were more sensitive than the others were. However, the calculated $\mathrm{IC}_{50}$ values of all the extracts were too high for considering as cytotoxic.
\end{abstract}

KEYWORDS: Antioxidant ; anti-inflammatory ; cytotoxicity ; free radical ; Ornithogalum sigmoideum.

\section{INTRODUCTION}

Oxidative stress is defined as an imbalance between the antioxidant defence system and the generation of the production of reactive oxygen and nitrogen species which are called free radicals. Oxidative stress can lead and exacerbate inflammation and expression of genes involved in inflammatory signaling pathways. Thus, excessive production of free radicals can trigger various oxidation and inflammation-related diseases such as asthma, arthritis, autoimmune diseases, cancer, cardiovascular diseases, diabetes, metabolic and endocrine diseases, neurological disorders, pulmonary and renal diseases [1]. Antioxidants are endogen and exogen substances, which can neutralize and suppress free radicals and provide protection of organisms against the harmful effects of these unstable structures. Antioxidants may help prevent or delay cell damage caused by oxidation and inflammation. Moreover these molecules have disease-fighting potentials against several chronic and degenerative disorders including autoimmune, cardiovascular, dermatologic, neurodegenerative, ocular and respiratory system diseases and even aging and cancer [2-5]. Polyphenols and flavonoids, which are found in almost all fruits and vegetables, are natural antioxidant and anti-inflammatory compounds [6-8].

Ornithogalum L. is a genus that distributes in temperate regions of Europe, Asia and Africa. It comprises about 200 species and 54 of them naturally grow in Turkey [9-14]. The fresh plants (bulbs, leaves, stems) have

How to cite this article: Yalçın CÖ, Yılmaz Sarıaltın S, Çiçek Polat D. Quantification of phenolic and flavonoid contents and some biological activities of Ornithogalum sigmoideum Freyn \& Sint. J Res Pharm. 2020; 24(4): 487-496. 
been widely consumed as vegetables both raw and cooked and sold on the local markets for many years [1418]. Some Ornithogalum species (sp.) have been reported to exhibit a wide range of biological activities such as anticancer, anti-inflammatory, antimicrobial, antioxidant and antitumor [9]. Ornithogalum sp. have long been used in the treatment of abscess and as emetic against poisoning since the time of Dioscorides. They are rich in cholestane glycosides, cholestane bidesmosides, cardenolide glycosides, flavonoid glycosides and saponins [14, 19-21]. A number of phenolic compounds have been reported in Ornithogalum sp. such as gallic acid, caffeic acid, protocatechuic acid, p-OH- benzoic acid, vanillic acid, ferulic acid and p-coumaric acid [9, 14].

Ornithogalum sigmoideum Freyn\&Sint. (O. sigmoideum), whose local name is "Sakarca, Çökülce and Tükürük otu", spreads throughout The Black Sea region [10,12]. Recent studies have been reported that different solvent extracts of $O$. sigmoideum showed moderate antioxidant activity according in vitro assays [14, 22].

This study aimed to evaluate cytotoxicity, antioxidant, anti-inflammatory effects and related total phenolic and flavonoid contents of aerial parts and bulbs of O. sigmoideum growing in Turkey. To the best of our knowledge, this is the first report on the anti-inflammatory and cytotoxic activity and total flavonoid content of $O$. sigmoideum.

\section{RESULTS AND DISCUSSION}

Many studies have been conducted on antioxidant properties and total amount of phenolic and flavonoid substances of Ornithogalum sp. [9, 14, 23-26]. It is known that polyphenolic substances and flavonoids have protective effects against various diseases such as cancers, cardiovascular diseases, osteoporosis and degenerative diseases, due to their antioxidant properties [27, 28]. However, there are only few reports on antioxidant activities of $O$. sigmoideum. The reports indicated that extracts possessed moderate antioxidant activities [14, 22].

In the present study; cytotoxicity, antioxidant and anti-inflammatory potentials of aerial parts and bulbs of $O$. sigmoideum were investigated. The half-maximal inhibitory concentrations $\left(\mathrm{IC}_{50}\right)$ of the extracts were calculated using calibration curves to evaluate these biological activities. Total phenolic and flavonoid contents of the extracts were expressed as gallic acid and quercetin equivalents, respectively to demonstrate their phytochemical characteristics and activities. Our study gains importance as O. sigmoideum is consumed as a traditional food and medicine.

No study has been reported with total phenolic and flavonoid content, antioxidant, anti-inflammatory and cytotoxic activity data of $O$. sigmoideum together. Moreover, this is the first report to demonstrate antiinflammatory and cytotoxicity activity as well as total flavonoid content of O. sigmoideum.

\subsection{Antioxidant activity}

ABTS and DPPH free radical scavenging assays are widely used to screen antioxidant capacities of plants, which measure the ability of a compound to scavenge ABTS and DPPH radicals respectively [29, 30]. The plant extracts possessed high and dose-dependent antioxidant capacities, in general.

ABTS free radical scavenging activities of extracts were shown in Table 1. Methanolic extracts of aerial parts of $O$. sigmoideum showed the highest ABTS free radical scavenging activity followed by aqueous extracts of aerial parts $\left(\mathrm{IC}_{50}=0.0449\right.$ and $0.0710 \mathrm{mg} / \mathrm{ml}$, respectively). Aqueous extracts of bulbs of O. sigmoideum had the lowest ABTS free radical scavenging capacity with $\mathrm{IC}_{50}$ values of $0.2142 \mathrm{mg} / \mathrm{ml}$. Our study is the first report on the ABTS radical scavenging activity of methanolic extracts of bulbs and aerial parts of $O$. sigmoideum. Similar to our results, one report suggested that hexanic, ethanolic and water extracts of $O$. sigmoideum exhibited moderate antioxidant activities through ABTS free radical scavenging and cupric reducing antioxidant capacity assays [22].

Table 2 revealed the total antioxidant activity, measured by DPPH free radical scavenging method. Methanolic extracts of aerial parts of $O$. sigmoideum exhibited the maximum inhibitor activity on DPPH free radical with $\mathrm{IC}_{50}$ values of $0.2172 \mathrm{mg} / \mathrm{ml}$; whereas positive standard butylated hydroxytoluene (BHT) showed $0.0161 \mathrm{mg} / \mathrm{ml}$. Similar to the results of ABTS assay, aqueous extracts of bulbs exhibited the lowest DPPH free radical inhibitory activity $\left(\mathrm{IC}_{50}=2.1864 \mathrm{mg} / \mathrm{ml}\right)$. Present study is the first report on the DPPH free radical scavenging activity of aqueous extracts of bulbs and aerial parts of $O$. sigmoideum. Another study was reported that methanolic extracts of $O$. sigmoideum aerial parts and bulbs showed antioxidant activities through ferricreducing antioxidant power, ferrous ion-chelating, phosphomolybdenum-reducing antioxidant power, DPPH and superoxide radical scavenging assays and were rich in phenolic compounds [14]. 
Table 1. Inhibitory effects of plant extracts on ABTS free radical.

\begin{tabular}{|c|c|c|}
\hline \multirow[t]{2}{*}{ Plant Name } & \multicolumn{2}{|c|}{$\begin{array}{c}\mathrm{IC}_{50} \\
(\mathrm{mg} / \mathrm{ml})\end{array}$} \\
\hline & Aqueous extract & Methanolic extract \\
\hline Control & - & - \\
\hline Ornithogalum sigmoideum (bulbs) & $0.2142 \pm 0.0216^{*}$ & $0.1560 \pm 0.0240^{*}$ \\
\hline Ornithogalum sigmoideum (aerial parts) & $0.0710 \pm 0.0008^{*}$ & $0.0449 \pm 0.0022^{*}$ \\
\hline Trolox & \multicolumn{2}{|c|}{$0.0107 \pm 0.0001^{*}$} \\
\hline
\end{tabular}

Table 2. Inhibitory effects of plant extracts on DPPH free radical.

\begin{tabular}{|c|c|c|}
\hline \multirow[t]{2}{*}{ Plant Name } & \multicolumn{2}{|c|}{$\begin{array}{c}\mathrm{IC}_{50} \\
(\mathrm{mg} / \mathrm{ml})\end{array}$} \\
\hline & Aqueous extract & Methanolic extract \\
\hline Control & - & - \\
\hline Ornithogalum sigmoideum (bulbs) & $2.1864 \pm 0.3464^{*}$ & $0.5766 \pm 0.0056^{*}$ \\
\hline Ornithogalum sigmoideum (aerial parts) & $0.2766 \pm 0.0162^{*}$ & $0.2172 \pm 0.0084^{*}$ \\
\hline BHT & \multicolumn{2}{|c|}{$0.0161 \pm 0.0002^{*}$} \\
\hline
\end{tabular}

* $\mathrm{p}<0.05$; Statistically significant compared to control. Data were expressed as mean \pm SEM.

\subsection{Anti-inflammatory activity}

All the extracts possessed recognizable HRBC membrane stabilization activity as shown in Table 3 . The results revealed that the percentage protection of HRBC membrane was found to be increased with concentration (Figure 1).

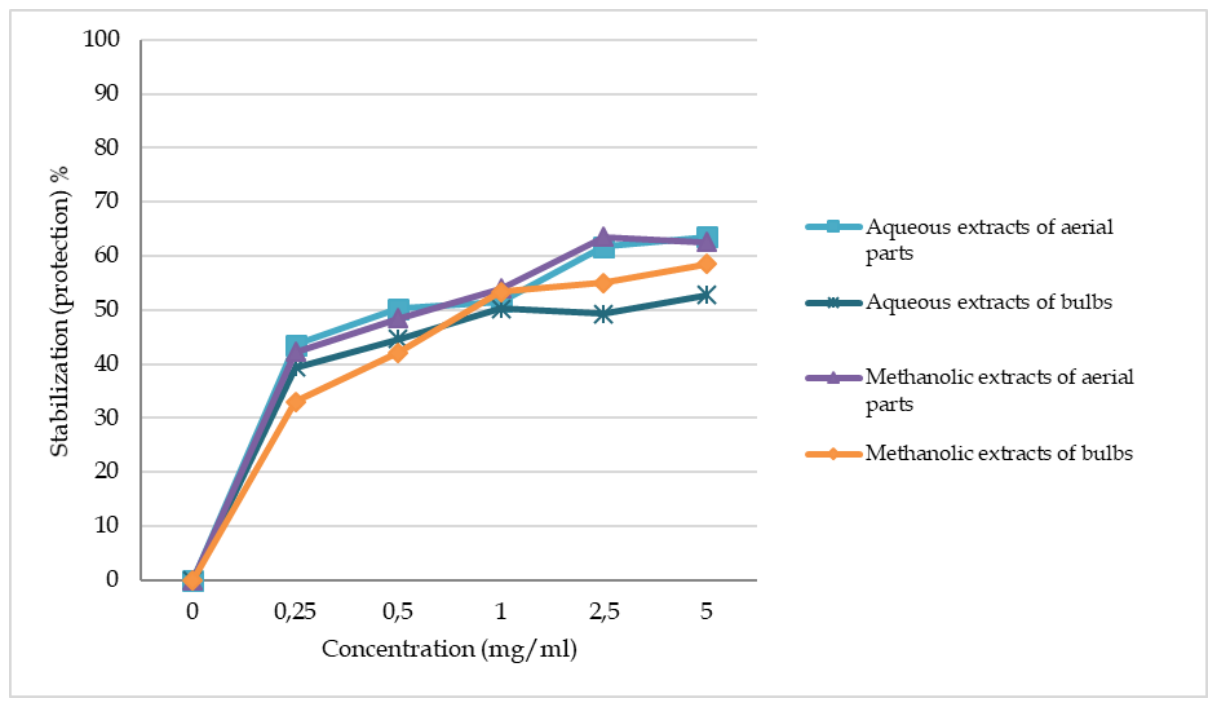

Figure 1. HRBC membrane stabilization (protection) activities of the extracts of O. sigmoideum.

In general, aerial parts exhibited higher anti-inflammatory activity than bulbs. Methanolic extracts of aerial parts of $O$. sigmoideum had the most potent protective effect on HRBC membrane with $\mathrm{IC}_{50}$ values of $0.7777 \mathrm{mg} / \mathrm{ml}$. Based on the comparison of the $\mathrm{IC}_{50}$ values, the order of the HRBC membrane stabilization activity was found to be as follows: methanolic extracts of aerial parts>aqueous extracts of aerial parts>methanolic extracts of bulbs>aqueous extracts of bulbs $(0.7777 \mathrm{mg} / \mathrm{ml} ; 0.8575 \mathrm{mg} / \mathrm{ml} ; 2.2333 \mathrm{mg} / \mathrm{ml}$ and $3.2726 \mathrm{mg} / \mathrm{ml}$, respectively. The $\mathrm{IC}_{50}$ value of acetylsalicylic acid (ASA), which was used as a reference drug, was $0.2979 \mathrm{mg} / \mathrm{ml}$. ASA exhibited higher HRBC membrane stabilizing activity than the most potent 
extract. According to the results observed, the extracts can be considered to exhibit intermediate antiinflammatory activity. Since the extracts are mixed structures, pure compounds can be found and isolate from these extracts which provide higher anti-inflammatory activity than ASA.

Table 3. Protective effects of plant extracts on HRBC membrane.

\begin{tabular}{|c|c|c|}
\hline \multirow[t]{2}{*}{ Plant Name } & \multicolumn{2}{|c|}{$\begin{array}{c}\mathrm{IC}_{50} \\
(\mathrm{mg} / \mathrm{ml})\end{array}$} \\
\hline & Aqueous extract & Methanolic extract \\
\hline Control & - & - \\
\hline Ornithogalum sigmoideum (bulbs) & $3.2726 \pm 0.2250^{*}$ & $2.2333 \pm 0.1036^{*}$ \\
\hline Ornithogalum sigmoideum (aerial parts) & $0.8575 \pm 0.0670^{*}$ & $0.7777 \pm 0.1233^{*}$ \\
\hline ASA & \multicolumn{2}{|c|}{$0.2979 \pm 0.0025^{*}$} \\
\hline
\end{tabular}

${ }^{*} \mathrm{p}<0.05$; Statistically significant compared to control. Data were expressed as mean \pm SEM.

\subsection{Total phenolic and flavonoid content}

Phenols and flavonoids were maximally present in aerial parts and methanolic extracts. The total phenolic contents of the examined plant extracts were calculated from a calibration curve using the FolinCiocalteu's method, and the results were expressed as $\mathrm{mg}$ gallic acid equivalent (GAE) per g extract $\left(\mathrm{r}^{2}=\right.$ 0.9908) (Table 4). Methanolic extract of aerial parts and bulbs of O. sigmoideum had the greatest phenolic contents ( 388.2105 and $378.7368 \mathrm{mg}$ GAE/g crude extract) respectively, while the lowest content was recorded for aqueous extracts of bulbs (243.1228 mg GAE/g crude extract).

Table 4. Total phenolic content of plant extracts

\begin{tabular}{lcc}
\hline \multirow{2}{*}{ Plant Name } & \multicolumn{2}{c}{ mg GAE /g extract } \\
\cline { 2 - 3 } & Aqueous extract & Methanolic extract \\
\hline Ornithogalum sigmoideum (bulbs) & $243.1228 \pm 2.4749$ & $378.7368 \pm 2.4119$ \\
Ornithogalum sigmoideum (aerial parts) & $344.5263 \pm 3.8795$ & $388.2105 \pm 1.0526$ \\
\hline
\end{tabular}

Data were expressed as mean \pm SEM.

The total flavonoid contents in the examined plant extracts using aluminium chloride colourimetric method were expressed in terms of quercetin equivalent $(\mathrm{QE})\left(\mathrm{r}^{2}=0.9902\right)$ and the results were expressed in Table 5. Among all, the highest amount of flavonoids was found in methanolic extracts of aerial parts of $O$. sigmoideum (107.0417 mg QE/g crude extract) followed by aqueous extracts of aerial parts $(79.7500 \mathrm{mg}$ QE/g crude extract). The lowest amount of flavonoids was found in aqueous extract of O. sigmoideum bulbs (57.6667 mg QE/g crude extract).

Table 5. Total flavonoid content of plant extracts

\begin{tabular}{lcc}
\hline \multirow{2}{*}{ Plant Name } & \multicolumn{2}{c}{ mg QE/g extract } \\
\cline { 2 - 3 } & Aqueous extract & Methanolic extract \\
\hline Ornithogalum sigmoideum (bulbs) & $57.6667 \pm 1.5404$ & $68.9167 \pm 2.3199$ \\
\hline Ornithogalum sigmoideum (aerial parts) & $79.7500 \pm 2.7847$ & $107.0417 \pm 0.6250$ \\
\hline
\end{tabular}

Data were expressed as mean \pm SEM.

\subsection{MTT cell viability assay}

The cytotoxic effects of methanolic extracts of bulbs and aerial parts of $O$. sigmoideum were investigated using MTT cell viability assay. The results were presented in Figure 2 and 3. Both bulb and aerial part extracts induced cell death in A549, HCT-116 and PC3 cells concentration-dependent manner. The cell viabilities were ranged from $88 \pm 5.2 \%$ to $24 \pm 5.8 \%, 98 \pm 5.0$ to $40 \pm 4.5 \%$ and $74 \pm 9.0 \%$ to $6 \pm 1.4 \%$ in A549, HCT- 116 and PC 3 cells, 
respectively at 100-1000 $\mu \mathrm{g} / \mathrm{ml}$ (Figure 2). In the aerial part extract-treated A549, HCT-116 and PC3 cells, for $25-1000 \mu \mathrm{g} / \mathrm{ml}$ concentrations, the cells viabilities were calculated as $72 \pm 5.7 \%$ to $4 \pm 0.6 \%, 96 \pm 3.0 \%$ to $4 \pm 0.4 \%$ and $76 \pm 9.0 \%$ to $7 \pm 0.3 \%$, respectively (Figure 3 ). According to the results, $\mathrm{IC}_{50}$ concentrations of bulb extracts $(586.80 \pm 33.3 ; 846.71 \pm 45.8 ; 274.62 \pm 33.6)$ were higher than aerial part extracts $(184.62 \pm 12.7 ; 187.79 \pm 17.3$; 81.24 \pm 9.0$)$ in A549, HCT-116, PC3 cells, respectively. According to the obtained results, the extracts cannot be considered as cytotoxic based on the criteria of the American National Cancer Institute (NCI). These values were farther than the criteria of a crude extract to evaluate as cytotoxic $\left(\mathrm{IC}_{50}<30 \mu \mathrm{g} / \mathrm{ml}\right)$, which was established by the NCI [31].

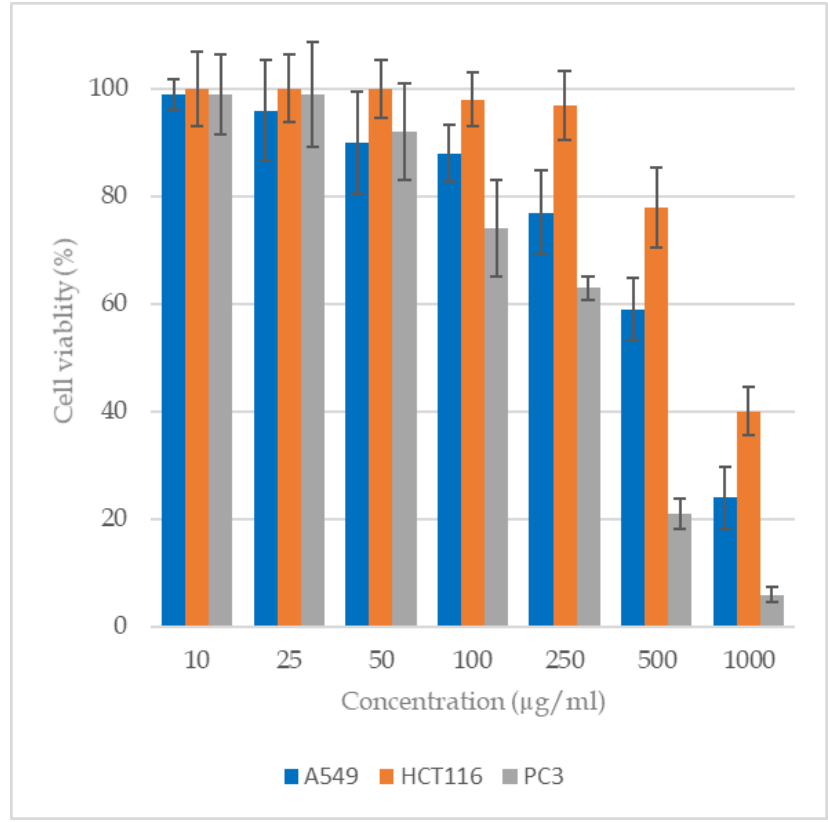

Figure 2. MTT results showed the cytotoxic effect of methanolic extracts of bulbs of O. sigmoideum in A549, HCT-116 cells and PC3 cells. The cells were treated with different concentrations $(10-1000 \mu \mathrm{g} / \mathrm{ml})$ of the extracts for $24 \mathrm{~h}$. Results are given as median of cell viability (\%). The error bar represents \pm SEM.

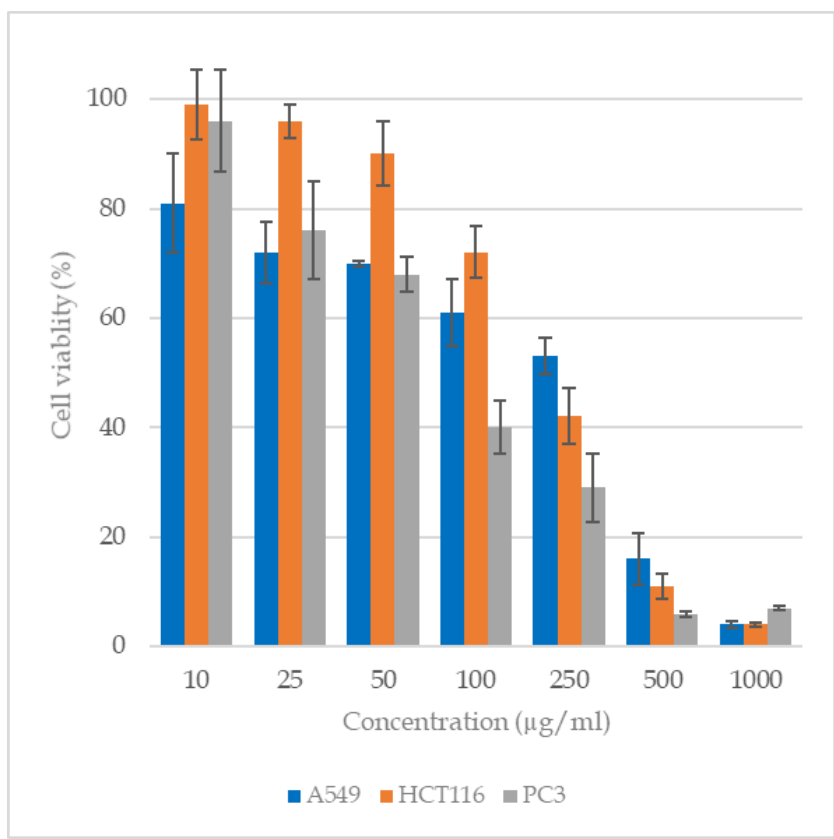

Figure 3. MTT results showed the cytotoxic effect of methanolic extracts of aerial parts of $O$. sigmoideum in A549, HCT-116 cells and PC3 cells. The cells were treated with different concentrations $(10-1000 \mu \mathrm{g} / \mathrm{ml}) \mathrm{of}$ the extracts for $24 \mathrm{~h}$. Results are given as median of cell viability (\%). The error bar represents \pm SEM. 


\section{CONCLUSION}

The current study reveals useful information about antioxidant, anti-inflammatory and cytotoxic properties and phenolic and flavonoid contents of different parts of O. sigmoideum. It was found that all the extracts possessed concentration-dependent inhibition of ABTS and DPPH free radicals. HRBC membrane stabilization activity of these extracts were increased in a concentration dependent manner as well. In general, aerial parts and methanolic extracts exhibited higher biological activities and also these are rich in phenolic and flavonoid compounds. These potentials of the extracts may be due to the presence of various phenolic and flavonoid compounds. The results also suggest that the methanolic extracts of aerial parts of O. sigmoideum was the best antioxidant and anti-inflammatory extract and the richest regarding to phenolic and flavonoids among all. The concentrations of cell death observed were too high to indicate the extracts as cytotoxic. As a consequence, $\mathrm{O}$. sigmoideum might be consumed safely as food and a promising source of potential antioxidant and anti-inflammatory compounds.

\section{MATERIALS AND METHODS}

\subsection{Chemicals}

ASA, aluminium chloride, BHT, Folin\&Ciocalteu's phenol reagent, gallic acid, methanol, potassium persulfate, sodium carbonate, sodium chloride, sodium nitrite, trolox, quercetin, ABTS, DPPH, dimethyl sulfoxide (DMSO) were purchased from Sigma-Aldrich (USA). Dulbecco's modified eagle medium (DMEM) in high glucose (Wisent, Canada), MTT (Serva, Germany), trypsin/EDTA (Multicell, USA), streptomycin/penicillin (Wisent, Canada) were purchased from commercial sources.

\subsection{Plant collection and identification}

O. sigmoideum, which is known as 'sakarca' by local people, was obtained from a Perşembe district bazaar in the city of Ordu-Turkey in May 2018. Each sample along with the aerial part and bulbs of the plant was authenticated by Dr. Derya Çiçek Polat from Ankara University.

\subsection{Preparation of extracts}

After samples (aerial parts and bulbs) were dried separately, they were powdered. The powdered samples were separately extracted with a magnetic stirrer methanol for methanolic extracts and distilled water for aqueous extracts $(50 \mathrm{~g}$ sample, $300 \mathrm{ml} \times 3)$. After being filtered, methanol extract was concentrated with a rotary evaporator and aqua extract was frozen at $-20^{\circ} \mathrm{C}$, then lyophilized. The methanol extracts yield of aerial parts and bulbs was calculated as $11.29 \%$ and $10.52 \%(\mathrm{w} / \mathrm{w})$ respectively. The aqueous extracts yield of aerial parts and bulbs was calculated as $15.12 \%$ and $13.81 \%(\mathrm{w} / \mathrm{w})$ respectively.

\subsection{Antioxidant activity}

\subsubsection{DPPH free radical scavenging activity}

The DPPH free radical scavenging activities of the extracts were determined by their ability to bleach the stable radical DPPH with slight modifications of the method of Blois [32]. The reaction mixture contained different concentrations of the extracts and DPPH in methanol. Absorbance was measured after 30 minutes incubation at $517 \mathrm{~nm}$ using a microplate reader. All the experiments were done in triplicate. BHT was used as a reference compound. The DPPH scavenging activity was calculated as the percentage of the radical reduction using the formula below.

Inhibition $(\%)=[($ Absorbance of control- Absorbance of sample $) /$ Absorbance of control $)] \times 100$

[Eq. 1]

$\mathrm{IC}_{50}$ values were determined from a calibration curve for each extract and the results were expressed as mean \pm SEM.

\subsubsection{ABTS free radical scavenging activity}

The method of Re et al. [33] was used to determine ABTS free radical cation decolourization activity of the extracts with minor modifications. ABTS was produced by reacting $7 \mathrm{mM}$ ABTS aqueous solution with $2.45 \mathrm{mM}$ potassium persulfate. The reaction mixture was allowed to stand in the dark at room temperature for 12-16 hours. Intensely-coloured ABTS radical cation was diluted with ethanol to give an absorbance value 
of $0.700 \pm 0.020$ at $734 \mathrm{~nm}(\mathrm{pH}=7.4)$. The absorbance of the reaction mixture, containing different concentrations of plant extracts and ABTS solution, was measured 6 minutes after addition to the wells at $734 \mathrm{~nm}$ using a microplate reader and the percentage of inhibition was calculated. All the experiments were done in triplicate. Trolox, the water-soluble a-tocopherol analogue, was used as a reference compound. . The ABTS scavenging activity was calculated as the percentage of the radical reduction using the formula below.

Inhibition $(\%)=[($ Absorbance of control- Absorbance of sample $) /$ Absorbance of control $)] \times 100$

[Eq. 2]

$\mathrm{IC}_{50}$ values were determined from a calibration curve for each extract and the results were expressed as mean \pm SEM.

\subsection{Anti-inflammatory activity}

HRBC membrane stabilizing activity of the extracts was determined as an indicator of antiinflammatory activity $[34,35]$. Fresh whole human blood was taken from healthy human volunteers who had not taken any steroidal, nonsteroidal anti-inflammatory or anticoagulant drugs for 4 weeks before the experiment. The tubes were centrifuged at $3000 \mathrm{rpm}$ for 10 minutes, then the packed cells were washed with isosaline $(0.85 \%, \mathrm{pH} 7.2)$ at least three times. $10 \% \mathrm{v} / \mathrm{v}$ suspension with isosaline was prepared. The reaction mixture consisted of test sample and $10 \%$ red blood cell suspension. All the centrifuge tubes containing reaction mixture were incubated at $56^{\circ} \mathrm{C}$ for 30 minutes. After the incubation, the tubes were cooled, and the reaction mixture was centrifuged at $2500 \mathrm{rpm}$ for 5 minutes. The absorbance was measured at $560 \mathrm{~nm}$ using a microplate reader. All the experiments were done in triplicate. ASA was used as a reference drug. The percentage of hemolysis and protection were calculated according to the formula:

Hemolysis \% $=($ Absorbance of sample $/$ Absorbance of control $) \times 100$

[Eq. 3]

Protection (Stabilization) \% = $100-[$ (Absorbance of sample/ Absorbance of control $) \times 100]$

[Eq. 4]

$\mathrm{IC}_{50}$ values were determined from a calibration curve for each extract and the results were expressed as mean \pm SEM.

\subsection{Phytochemical screening}

\subsubsection{Determination of total phenolic content}

The amount of total phenolic content in the extracts was determined with the Folin-Ciocalteu method with minor modifications [36]. Total phenolic content was determined from a standard curve of different concentrations of gallic acid. Total phenolic contents were expressed as mg GAE per g crude extract.

\subsubsection{Determination of total flavonoid content}

The amount of total flavonoid content in the extracts was determined by the aluminium chloride colourimetric method with minor modifications [37]. Total flavonoid content was determined from a standard curve of different concentrations of quercetin. Total flavonoid content was expressed as mg QE per g crude extract.

\subsection{Cytotoxicity}

\subsubsection{Cell culture}

Human colorectal (HCT-116) (ATCC®CCL-247TM), lung (A549) (ATCC®CCL-185TM) and prostate (PC3) (ATCC®CCL-1435TM) cancer cell lines were grown in high glucose DMEM supplemented with 10\% fetal bovine serum, $1 \%$ penicillin $(100 \mathrm{U} / \mathrm{ml})$ and streptomycin $(100 \mu \mathrm{g} / \mathrm{ml})$, and maintained at $37^{\circ} \mathrm{C}$ in $5 \%$ $\mathrm{CO}_{2}$ incubator. The passage process was performed twice a week and culture media was changed after every 2 days. The cells were treated with Trypsin-EDTA (0.25\%) and sub-cultured when reached to $90 \%$ confluence into 6/96 well plates or $25 \mathrm{~cm}^{2}$ flasks according to the assay. 


\subsubsection{MTT cell viability assay}

Cells were seeded in 96-well plates quantities of $1 \times 10^{4} /$ well for $24 \mathrm{~h}$. The stock solutions of $1000 \mathrm{mg} / \mathrm{ml}$ extracts were dissolved in methanol, after removing the culture medium, cells were treated with exposure medium containing the extracts (final concentrations: 10, 25, 50, 100, 250, 500, and $1000 \mu \mathrm{g} / \mathrm{ml}$ ). DMSO 10\% and methanol $0.4 \%$ was used as positive and solvent controls, respectively. Plates were incubated in $37^{\circ} \mathrm{C}$, humidified incubator with $5 \% \mathrm{CO}_{2}$ for $24 \mathrm{~h}$. Afterwards, the medium was changed with $100 \mu \mathrm{l}$ of serum-free medium containing $0.5 \mathrm{mg} / \mathrm{ml}$ MTT to each well and incubated at $37^{\circ} \mathrm{C}$ for $4 \mathrm{~h}$. Thereafter, the MTT containing medium was gently removed. For dissolving formazan crystals $150 \mu \mathrm{DMSO}$ was added to each well and then shaken for $10 \mathrm{~min}$. The absorbance was measured at 570 and $690 \mathrm{~nm}$ using a microplate reader [38]. The percentage of cell viability was calculated according to the formula:

Cell viability $\%=(($ Absorbance of control-Absorbance of treat $) /$ Absorbance of control $) \times 100$

[Eq. 5]

\subsection{Statistical analysis}

IBM SPSS Statistics for Windows, Version 25.0. (Armonk, NY: IBM Corp.) was used for statistical analysis of results. Results were expressed as mean value \pm standard error of the mean (SEM). All the assays were conducted at least in triplicates. The linear regression analysis was performed to find out the correlation coefficient. Statistical significance was evaluated employing one-way analysis of variance (ANOVA) and post hoc LSD test. A p-value of less than 0.05 was considered as statistically significant.

Acknowledgements: This research did not receive any specific grant from funding agencies in the public, commercial, or not-for-profit sectors.

Author contributions: Concept - C.Ö.Y., S.Y.S., D.Ç.P.; Design - C.Ö.Y.; Supervision - C.Ö.Y..; Resources - C.Ö.Y., S.Y.S., D.Ç.P.; Materials - C.Ö.Y., S.Y.S., D.Ç.P.; Data Collection and/or Processing - C.Ö.Y., S.Y.S., D.Ç.; Analysis and/or Interpretation - C.Ö.Y., S.Y.S., D.Ç.P. ; Literature Search - C.Ö.Y., S.Y.S., D.Ç.P.; Writing - C.Ö.Y., S.Y.S., D.Ç.P.; Critical Reviews - C.Ö.Y., S.Y.S., D.Ç.P.

Conflict of interest statement: The authors declared no conflict of interest.

\section{REFERENCES}

[1] Tan BL, Norhaizan ME, Liew WPP, Sulaiman Rahman H. Antioxidant and oxidative stress: A mutual interplay in age-related diseases. Front Pharm. 2018; 9: 1162. [CrossRef]

[2] Xu DP, Li Y, Meng X, Zhou T, Zhou Y, Zheng J, Zhang JJ, Li HB. Natural antioxidants in foods and medicinal plants: Extraction, assessment and resources. J Mol Sci. 2017; 18(1): 96. [CrossRef]

[3] Magder S. Reactive oxygen species: toxic molecules or spark of life? Critical Care. 2006; 10(1), 208. [CrossRef]

[4] Sarialtin SY, Coban T. An Overview on the Role of Macular Xanthophylls in Ocular Diseases. Rec Nat Prod. 2018; 12(2): 107-120. [CrossRef]

[5] Liguori I, Russo G, Curcio F, Bulli G, Aran L, Della-Morte D, Gargiulo G, Testa G, Cacciatore F, Bonaduce D, Abete, P. Oxidative stress, aging, and diseases. Clin Interv Aging. 2018; 13: 757. [CrossRef]

[6] Jaradat NA, Zaid AN, Hussen F, Ali I. The effects of preservation methods of grapevine leaves on total phenols, total flavonoids and antioxidant activity. Marmara Pharm J. 2017; 21(2): 291-297. [CrossRef]

[7] Telkoparan Akillilar P, Tuglu YB, Shomali Moghaddam N. Anticancer, antioxidant properties and phenolic, flavonoid composition of Heracleum platytaenium plant methanolic extracts. Marmara Pharm J. 2018; 22(3). [CrossRef]

[8] Polat DÇ, Sarıaltın SY, Çoban T, Coşkun M. Comparison of Walnut (Juglans regia L.) and Olive (Olea europaea L.) Leaves in Terms of Antioxidant and Anti-inflammatory Activity. ADYU J Sci. 2019; 9(2): 242-251. [CrossRef]

[9] Plančić M, Božin B, Kladar N, Rat M, Srđenović B. Phytochemical profile and biological activities of the genus Ornithogalum L. (Hyacinthaceae). Biologia Serbica. 2014; 36(1-2): 1-17.

[10] Cullen J. Ornithogalum L., In: Flora of Turkey and East Aegean Islands, ed: P. H. Davis, Vol.8, Edinburgh University Press, Edinburgh. 1984; 227-245. 
[11] Davis PH, Mill RR, Tan K. Flora of Turkey and the East Aegean Islands, Vol.10 (supplement I), Edinburgh University Press, Edinburgh. 1988; 223-225.

[12] Özhatay N. Ornithogalum L. (Suppl. 2), vol. 11. In: Güner A, Özhatay NF, Ekim T, Başer KHC, editors. Flora of Turkey and the East Aegean Islands. Edinburgh: Edinburgh University Press. 2000; 233-237.

[13] Uysal T. Ornithogalum. In: Güner A, Aslan S, Ekim T, Vural M, Babac, MT, editors. Türkiye Bitkileri Listesi. Istanbul, Turkey: Nezahat Gokyiğit Botanik Bahçesi Araștırmaları Derneğ, 2012; 100-105.

[14] Renda G, Özel A, Turumtay EA, Barut B, Korkmaz B, Ayvaz MÇ, Demir A. Comparison of phenolic profiles and antioxidant activity of three Ornithogalum L. species. Turk J Biochem. 2018; 44(3): 299-306. [CrossRef]

[15] Baytop T. Türkiye'de Bitkilerle Tedavi 2. Baskı, Nobel Tıp Kitabevi, Istanbul. 1999; p. 146.

[16] Özbucak TB, Kutbay HG, Akcın OE. The Contribution of Wild Edible Plants to Human Nutrition in the Black Sea Region of Turkey. Ethnobot Leaflets. 2006; 10: 98-103.

[17] Özbucak TB, Akcın OE, Yalçın S. Nutrition contents of the some wild edible plants in Central Black Sea Region of Turkey. Int J Nat Eng Sci. 2007; 1: 11-13.

[18] Arslanoğlu ŞF. Some Medicinal Plants Gathered from Natural Areas. Lucrări Științifice, 2016; 59(2), 173-175.

[19] Ghannamy U, Kopp B, Robien W, Kubelka W. Cardenolide aus Ornithogalum boucheanum1. Planta Med. 1987; 53(02): 172-178. [CrossRef]

[20] Kubo S, Mimaki Y, Terao M, Sashida Y, Nikaido T, Ohmoto T. Acylated cholestane glycosides from the bulbs of Ornithogalum saundersiae. Phytochem. 1992; 31(11): 3969-3973. [CrossRef]

[21] Şabudak T, Oyman Ü. Phytochemical studies at the bulbs of Ornithogalum umbellatum L. Turk J Chem. 2002; 26(3): 453-456.

[22] Kurt BZ, Gazioğlu I, Sevgi E, Sönmez F. Anticholinesterase, antioxidant, antiaflatoxigenic activities of ten edible wild plants from Ordu Area, Turkey. Iran J Pharm Sci. 2018; 17(3): 1047.

[23] Delazar A, Nazifi E, Movafeghi A, Nazemiyeh H, Hemmati S, Nahar L, Sarker SD. Analyses of phytosterols and free radical scavengers in the bulbs of Ornithogalum cuspidatum Bertol. Bol latinoam Caribe Plantas Med Aromát. 2010; 9(2): 87-92.

[24] Özen T. Antioxidant activity of wild edible plants in the Black Sea Region of Turkey. Grasas y aceites. 2010; 61(1): 8694. [CrossRef]

[25] Makasci AA, Mammadov R, Dusen O, Isik HI. Antimicrobial and antioxidant activities of medicinal plant species Ornithogalum alpigenum stapf. from Turkey. J Med Plant Res. 2010; 4(16): 1637-1642. [CrossRef]

[26] Zengin G, Uysal S, Ceylan R, Aktumsek A. Phenolic constituent, antioxidative and tyrosinase inhibitory activity of Ornithogalum narbonense L. from Turkey: a phytochemical study. Ind Crops Prod. 2015; 70: 1-6. [CrossRef]

[27] Pandey KB, Rizvi SI. Plant polyphenols as dietary antioxidants in human health and disease. Oxid Med Cell Longev. 2009; 2(5): 270-278. [CrossRef]

[28] Sipahi H, Gostner JM, Becker K, Charehsaz M, Kirmizibekmez H, Schennach H, Aydin A, Fuchs D. Bioactivites of two common polyphenolic compounds: Verbascoside and catechin. Pharm Biol. 2016; 54(4): 712-719. [CrossRef]

[29] Embuscado ME. Spices and herbs: Natural sources of antioxidants-a mini review. J Func Foods. 2015; 18: 811-819. [CrossRef]

[30] Mirzadeh M, Arianejad MR, Khedmat L. Antioxidant, antiradical, and antimicrobial activities of polysaccharides obtained by microwave-assisted extraction method: A review. Carbohydr Polym. 2019; 115421. [CrossRef]

[31] A Itharat, PJ Houghton, E Eno-Amooquaye, PJ Burke, JH Sampson, A Raman. In vitro cytotoxic activity of Thai medicinal plants used traditionally to treat cancer. J Ethnopharmacol. 2004; 90: 33-38. [CrossRef]

[32] Blois MS. Antioxidant determinations by the use of a stable free radical. Nature. 1958; 181: 1199-1200. [CrossRef]

[33] Re R, Pellegrini N, Proteggente A, Pannala A, Yang M, Rice-Evans C. Antioxidant activity applying an improved ABTS radical cation decolorization assay. Free Radic Biol Med. 1999; 26: 1231-1237. [CrossRef]

[34] Shinde UA, Phadke AS, Nair AM, Mungantiwar AA, Dikshit VJ, Saraf MN. Membrane stabilizing activity - a possible mechanism of action for the anti-inflammatory activity of Cedrus deodara wood oil. Fitoterapia. 1999; 70: 251-257. [CrossRef] 
[35] Okur ME, Polat DC, Ozbek H, Yilmaz S, Yoltas A, Arslan R. Evaluation of the antidiabetic property of Capparis Ovata Desf. Var. Palaestina Zoh. Extracts using in vivo and in vitro approaches. Endocr Metab Immune Disord Drug Targets. 2018; 18(5): 489-501.

[36] Spanos GA, Wrolstad RE. Influence of processing and storage on the phenolic composition of Thompson seedless grape juice.J. Agric Food Chem. 1990; 38(7): 1565-1571. [CrossRef]

[37] Zhishen J, Mengcheng T, Jianming W. The determination of flavonoid contents in mulberry and their scavenging effects on superoxide radicals. Food Chem. 1999; 64: 555-559. [CrossRef]

[38] Yalçın CÖ, Baş H, Barut B, Özel A, Bıyıklığlu Z. Synthesis of axially disubstituted quaternized silicon phthalocyanines as a promising photosensitizer for photodynamic treatment of HCT-116, A549 and SH-SY5Y cancer cell lines. Dalton Trans. 2020; 49: 4927-4934. [CrossRef]

This is an open access article which is publicly available on our journal's website under Institutional Repository at http://dspace.marmara.edu.tr. 